\title{
Maturation of pancreatic $\beta$-cell function in the fetal horse during late gestation
}

\author{
A L Fowden, D S Gardner, J C Ousey, D A Giussani \\ and A J Forhead \\ Department of Physiology, University of Cambridge, Downing Street, Cambridge CB2 3EG, UK \\ (Requests for offprints should be addressed to A Fowden; Email: alf1000@cam.ac.uk)
}

\begin{abstract}
At birth, the endocrine pancreas becomes more directly involved in the control of glycaemia than in utero. However, compared with other tissues, relatively little is known about the maturational changes that occur in the fetal endocrine pancreas in preparation for extrauterine life. This study examined the pancreatic $\beta$-cell response to exogenous administration of glucose and arginine in fetal horses with respect to their gestational age and concentration of cortisol, the hormone responsible for prepartum maturation of other fetal tissues. Glucose administration had no effect on fetal insulin secretion between 175 and 230 days of gestation but evoked a rapid insulin response in fetuses closer to term (290-327 days). In late gestation, the
\end{abstract}

$\beta$-cell response was more rapid and greater in magnitude in fetuses with basal cortisol levels higher than $15 \mathrm{ng} / \mathrm{ml}$ than in those with lower cortisol values at the time of glucose administration. The fetal $\beta$-cell response to arginine was unaffected by the rise in fetal plasma cortisol towards term. These findings show that there are maturational changes in pancreatic $\beta$-cell function in fetal horses as cortisol levels rise close to term. Primarily, these prepartum maturational changes were in the mechanisms of glucose-stimulated insulin secretion, which would enable the $\beta$ cells to regulate glycaemia at the higher glucose levels observed postnatally.

Journal of Endocrinology (2005) 186, 467-473

\section{Introduction}

The endocrine pancreas is functional before birth and secretes insulin in utero in response to glucose and amino acids in several species including the horse (Gersch et al. 1974, Fowden 1980a,b, 1982a,b, Bassett et al. 1982, Carver et al. 1996, Gresores et al. 1997, Aldoretta et al. 1998). Fetal pancreatic $\beta$ cells also respond to neural stimulation and to circulating catecholamines during late gestation (Fowden 1980b, Sperling et al. 1980, Lang et al. 1993, Jackson et al. 2000). Insulin released by the fetal pancreas stimulates glucose uptake and lowers the circulating concentration of glucose in the fetus (see Fowden 1993). Hence, fetal $\beta$ cells both regulate and are regulated by the circulating glucose level in the fetus. However, since fetal glycaemia is dependent primarily on maternal glucose availability and the trans-placental transfer of glucose (Hay 1995), the main role of the endocrine pancreas in utero is not to regulate the fetal glucose level per se but to match the rate of fetal glucose utilisation to the rate of placental glucose supply (Fowden 1995, Fowden \& Hill 2001). At birth, the placental source of glucose is lost and replaced by a more intermittent supply of nutrients via the gut. Consequently, the endocrine pancreas must become directly involved in the control of glycaemia shortly after birth, if the neonate is to survive the transition from parenteral to enteral nutrition (Trahair \& Sangild 1997, Fowden et al. 2001).

In many fetal tissues, the maturational changes essential for neonatal survival begin before birth and are dependent upon the increase in fetal cortisol concentration towards term (Fowden et al. 1998). In fetal sheep, there are increases in pancreatic $\beta$-cell sensitivity to glucose and arginine between mid and late gestation (Fowden 1980a, Aldoretta et al. 1998). Similarly, in an earlier study of six fetal horses between mid and late gestation, exogenous glucose only stimulated insulin secretion in the three animals closest to term (Fowden et al. 1980). However, little is known about the ontogenic changes in the $\beta$-cell responses to glucose and arginine in either of these species during the period of late gestation when other fetal tissues are maturing in response to the prepartum rise in fetal plasma cortisol. In foals delivered prematurely before the cortisol rise, pancreatic $\beta$-cell sensitivity to glucose is poor immediately after birth compared with the full-term neonates (Fowden et al. 1982b). These observations suggest that there may be maturational changes in pancreatic $\beta$-cell function in the fetus in the period immediately before birth.

In the horse, the normal range of gestational ages at spontaneous delivery at term is wide compared with other 
species and varies from 315 to 365 days (Rossdale 1967). Fetal plasma cortisol concentrations rise before delivery in the horse, as in other species, but the increment is relatively rapid and occurs much closer to term in the horse than in other species (Silver \& Fowden 1994). The fetal cortisol concentration is, therefore, a better index of proximity to delivery than gestational age in the horse. However, whether the prepartum rise in plasma cortisol is linked to pancreatic $\beta$-cell maturation in the fetus in this and any other species remains unknown. This study, therefore, investigated the pancreatic $\beta$-cell responses to glucose and arginine in fetal horses in relation to their gestational age and cortisol concentration.

\section{Methods}

\section{Animals}

Twenty-three pony mares $(250-330 \mathrm{~kg}$ ) of known gestational age were used in this study. They were housed in separate horse boxes and fed hay ad libitum and concentrates twice per day (500 g at 0800 and 1700 h; Dodson \& Horrell, Kettering, Northamptonshire, UK). The mares delivered between 4 and 164 days after the end of the study. Fourteen mares delivered viable foals spontaneously at a mean gestational age of $322 \pm 4$ days (term is approximately $325-330$ days in pony mares). The remaining 9 mares delivered non-viable foals before term either spontaneously for unexplained reasons $(n=3)$ or by induction as part of another study $(n=6)$. All procedures were carried out under the Animal (Scientific Procedures) Act 1986 of the UK Government.

\section{Operative procedures}

Food, but not water, was withdrawn $18 \mathrm{~h}$ before surgery and the cyclooxygenase inhibitor, meclofenamic acid (2 mg/kg Arquel; Pharmacia \& Upjohn, Sussex, UK), was given orally the night before surgery and twice daily for 2 days thereafter to reduce endogenous prostaglandin production associated with fasting and surgery (Silver \& Fowden 1994). Between 165 and 300 days of gestation, the mares were pre-medicated and, then, anaesthetised with a bolus dose of ketamine $(2 \mathrm{mg} / \mathrm{kg}$ bolus) followed by a continuous intravenous infusion of propofol $(0 \cdot 13$ $0.20 \mathrm{mg} / \mathrm{kg}$ per min Rapinovet; Shering-Plough, Harefield, UK) as described previously (Taylor et al. 2001). After induction of anaesthesia, the mare was placed in right lateral recumbency and the uterus was exposed through a midline abdominal incision. The position of the fetal hindlimb was ascertained by palpation and the foot was exteriorised by making a series of small incisions sequentially through the uterus, placenta and amnion. Polyvinyl catheters (outer diameter (OD), $1.52 \mathrm{~mm}$; inner diameter (ID), $0.86 \mathrm{~mm}$; Critchley, Electrical Products
Ltd, Silverwater, New South Wales, Australia) were inserted into the metatarsal artery and vein, and then advanced into the dorsal aorta and caudal vena cava of the fetus. The amnion was closed by tying its edges around the catheters using linen (5.0 metric size 2; Barbour, Lisburn, Northern Ireland). The placenta and uterine incisions were closed using resorbable sutures (Dexon 3.5 Metric Dexon-II BiColour; Genusexpress, Bury St Edmunds, Suffolk, UK). A uterine vein draining the area close to the incision site was catheterised and the tip of the catheter advanced $30-40 \mathrm{~cm}$ into a main uterine vein. All catheters were exteriorised through a keyhole incision in the maternal abdominal wall in the region of the flank. The peritoneum and abdominal layers were closed sequentially using absorbable sutures (Dexon). Finally, the skin incisions were closed with nylon (Prolene, Ethicon, 3.5 metric; Johnson \& Johnson International, Brussels, Belgium). An antibiotic was given intravenously to the fetus at the end of surgery $(25 \mathrm{mg} / \mathrm{kg}$ ampicillin, Penbritin; GlaxoSmithKline) and to the mother (1 $\mathrm{g}$ ampicillin) on the day of surgery and for 3 days thereafter. Patency of the fetal catheters was maintained by continuous infusion of heparin-saline $(2.5 \mathrm{ml} /$ day of $200 \mathrm{IU}$ heparin $/ \mathrm{ml}$ in $0.9 \%$ $\mathrm{w} / \mathrm{v} \mathrm{NaCl}$ ) using small portable pumps (Graseby Medical, Watford, UK) housed in a bag secured to the flank of the mare. Normal feeding patterns were generally resumed within 24-36 h after surgery.

\section{Experimental procedures}

At least 7 days after surgery, fetuses were infused intravenously with either glucose $(0.5 \mathrm{~g} / \mathrm{kg}$ estimated fetal body weight, 50\% dextrose (Arnold Ltd, Shrewsbury, Shropshire, UK), $n=18)$ or arginine $(100 \mathrm{mg} / \mathrm{kg}$ estimated fetal body weight, Sigma, $n=10)$ over $5 \mathrm{~min}$. Two animals received both a glucose and arginine infusion separated by at least 5 days. Blood samples of $3 \mathrm{ml}$ were taken from the fetal artery at 5-15 min intervals for $30 \mathrm{~min}$ before and 60 min after infusion and then at 30-min intervals until $120 \mathrm{~min}$ after infusion. Blood samples were centrifuged immediately at $4{ }^{\circ} \mathrm{C}$ and the plasma was stored at $-20^{\circ} \mathrm{C}$ until analysis for glucose, $\alpha$-amino-nitrogen, insulin and cortisol concentrations.

\section{Biochemical analyses}

Blood $\mathrm{pH}$ and gas tensions were measured using a blood gas analyser (Radiometer ABL3, Copenhagen, Denmark). Plasma concentrations of glucose were measured using a Yellow Springs analyser (YSI 2300 Stat Plus; Yellow Springs, OH, USA) while plasma $\alpha$-amino-nitrogen levels were measured colorimetrically as described previously (Fowden et al. 1986). Plasma concentrations of insulin and cortisol were measured by radioimmunoassay validated for use with equine plasma (Fowden et al. 1980, Rossdale et al. 1982). The minimum detectable levels of insulin and 
Table 1 Mean ( \pm S.E.M.) arterial values of blood $\mathrm{pH}$ and gas tensions and of the plasma concentrations of cortisol, insulin, glucose and $\alpha$-amino-nitrogen in fetuses before administration of glucose or arginine in the different groups of animals (Group $1,175-230$ days, $n=5$ fetuses; Group 2, 290-327 days with fetal cortisol concentrations $<15 \mathrm{ng} / \mathrm{ml}$ (Group 2a, $n=9$ fetuses) or $>15 \mathrm{ng} / \mathrm{ml}$ (Group 2b, $n=9$ fetuses))

\begin{tabular}{|c|c|c|c|c|c|c|c|}
\hline & Blood pH & $\begin{array}{l}\mathbf{p O}_{2} \\
(\mathrm{mmHg})\end{array}$ & $\begin{array}{l}\mathbf{p C O _ { 2 }} \\
(\mathrm{mmHg})\end{array}$ & $\begin{array}{l}\text { Cortisol } \\
(\mathrm{ng} / \mathrm{ml})\end{array}$ & $\begin{array}{l}\text { Insulin } \\
(\mu \bigcup / \mathrm{ml})\end{array}$ & $\begin{array}{l}\text { Glucose } \\
(\mathrm{mmol} / \mathrm{l})\end{array}$ & $\begin{array}{l}\boldsymbol{\alpha} \text {-Amino-nitrogen } \\
(\mathrm{mmol} / \mathrm{l})\end{array}$ \\
\hline Group 1 & $7 \cdot 37 \pm 0.02$ & $41 \cdot 5 \pm 4 \cdot 4^{a}$ & $48 \cdot 9 \pm 3 \cdot 7$ & $9 \cdot 8 \pm 0 \cdot 8^{a}$ & $6 \cdot 0 \pm 1 \cdot 1$ & $2 \cdot 79 \pm 0.36$ & - \\
\hline Group 2a & $7 \cdot 36 \pm 0 \cdot 01$ & $27 \cdot 7 \pm 2 \cdot 6^{b}$ & $57 \cdot 7 \pm 2 \cdot 4$ & $10 \cdot 8 \pm 0 \cdot 8^{a}$ & $8 \cdot 2 \pm 1 \cdot 2$ & $3 \cdot 22 \pm 0 \cdot 20$ & $3 \cdot 30 \pm 0 \cdot 18$ \\
\hline Group 2b & $7 \cdot 36 \pm 0 \cdot 01$ & $30 \cdot 1 \pm 2 \cdot 5^{b}$ & $51 \cdot 8 \pm 2 \cdot 5$ & $29 \cdot 7 \pm 5 \cdot 1^{b}$ & $9 \cdot 9 \pm 1 \cdot 6$ & $2 \cdot 95 \pm 0.23$ & $3 \cdot 46 \pm 0 \cdot 30$ \\
\hline
\end{tabular}

Values within columns with different superscript letters are significantly different from each other $(P<0 \cdot 05$, ANOVA).

cortisol were $2 \cdot 0 \mu \mathrm{U} / \mathrm{ml}$ and $1.5 \mathrm{ng} / \mathrm{ml}$ respectively. The inter-assay coefficient of variation was $11.5 \%$ for the insulin assay and $8 \%$ for the cortisol assay.

\section{Data and statistical analyses.}

The animals were divided into two groups on the basis of gestational age. Group 1 was between 175 and 230 days of gestation ( $n=5$ animals) while Group 2 was between 290 and 327 days of gestation ( $n=18$ animals). The Group 2 animals were then subdivided on the basis of the fetal plasma cortisol concentration at the time of glucose or arginine administration. Group 2a had cortisol concentrations lower than $15 \mathrm{ng} / \mathrm{ml} \quad(n=9$ animals $)$ while Group $2 \mathrm{~b}$ had cortisol concentrations higher than $15 \mathrm{ng} / \mathrm{ml}$ ( $n=9$ animals). The concentration threshold of $15 \mathrm{ng} / \mathrm{ml}$ was chosen because this is the value at which the prepartum cortisol surge has irreversibly begun and when delivery is imminent with less than 10 days of gestation remaining (Silver \& Fowden 1994). The mean gestational ages of Group 2a (mean, $303 \pm 3$ days; range, 292-320 days; $n=9$ animals) and Group 2b (mean, $312 \pm 7$ days; range, 295-327 days; $n=9$ animals) were not significantly different. Arginine was not given to any fetuses in Group 1.

All results are expressed as means \pm S.E. Comparisons within and between groups were made using either one-way or two-way ANOVA with or without repeated measures followed by the Tukey post-hoc tests, as appropriate. For each glucose or arginine challenge, the areas under the insulin, glucose or $\alpha$-amino-nitrogen response curves were calculated by integrating the increment in plasma concentration - after administration of glucose or arginine (from 5 to $120 \mathrm{~min}$ ) - above the pre-infusion baseline $(0 \mathrm{~min})$. Linear and partial correlation analyses were carried out according to the methods of Armitage and Berry (1994) using SPSS software (SigmaStat; Clecom, Edgbaston, Birmingham, UK). The maximum increments in the insulin concentration in response to glucose were linearly related to plasma cortisol concentrations and gestational age. Partial correlation analysis was used to assess the relationship between these three variables.

\section{Results}

\section{Basal metabolite and insulin concentrations}

In common with previous findings (Fowden et al. 1982b, 1999), there were no significant changes in the basal arterial concentrations of plasma insulin, glucose and $\alpha$-amino-nitrogen with gestational age in the fetuses; mean values before administration of glucose or arginine were similar in Groups 1 and 2 (Table 1). There were also no significant differences in the basal arterial concentrations of plasma insulin, glucose and $\alpha$-aminonitrogen between Group 2a and Group $2 \mathrm{~b}$ fetuses in association with the rise in cortisol concentrations towards term (Table 1). Arterial blood $\mathrm{pH}$ and $\mathrm{pCO}_{2}$ tensions were similar in all groups but blood $\mathrm{pO}_{2}$ tension was higher in Group 1 than in Group 2 fetuses (Table 1) as observed previously (Giussani et al. 2005). Fetal arterial concentrations of plasma cortisol were significantly higher in Group 2b than in either Group 1 or Group 2a (Table 1).

\section{Pancreatic $\beta$-cell responses}

Glucose Glucose administration had no apparent effect on insulin secretion in Group 1 fetuses but evoked a rapid insulin release in older Group 2 fetuses (Fig. 1). In Group 2, the fetal $\beta$-cell response to glucose occurred more rapidly and was greater in magnitude in the fetuses with cortisol levels higher than $15 \mathrm{ng} / \mathrm{ml}$ (Group 2b) than in those with lower cortisol values (Group 2a, Fig. 1). The maximum increment in insulin and the insulin area under the curve (AUC) in response to glucose was significantly greater in Group $2 \mathrm{~b}$ than in Group 1 or Group 2a (Table 2). The peak insulin concentration occurred immediately after the end of the 5-min infusion in all Group $2 \mathrm{~b}$ fetuses but was delayed until 10 min after the end of infusion in all Group 2a fetuses. There was no gestational trend in the fetal $\beta$-cell response to glucose in any of the three groups. When the data from all groups were combined, there were significant positive correlations between the maximum increment in insulin in response to glucose and both the basal, pre-infusion 

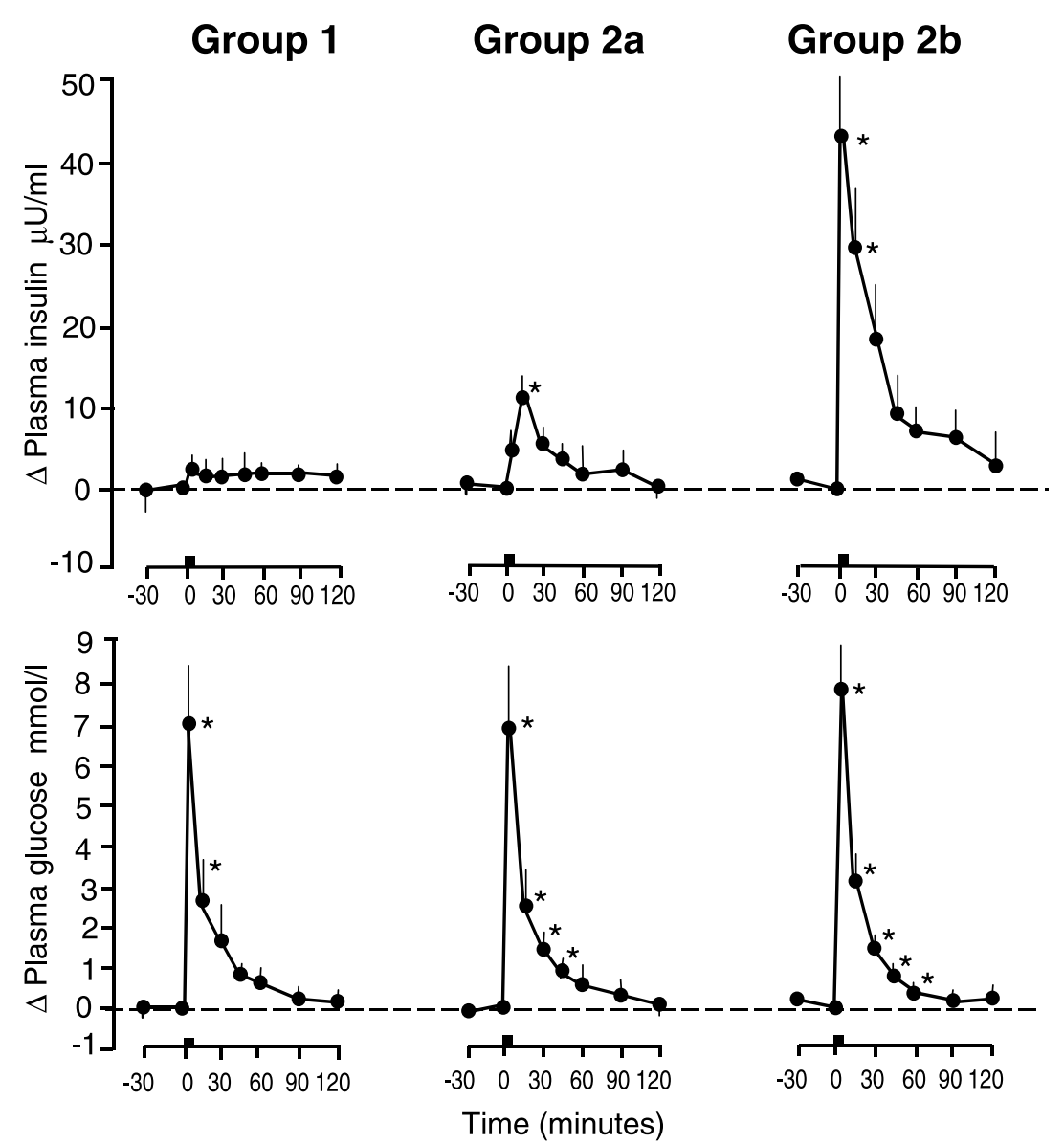

Figure 1 Mean ( \pm S.E.M.) increments in arterial concentrations of plasma insulin and glucose from the basal pre-infusion $(0 \mathrm{~min})$ value after administration of glucose (solid bar) in the three groups of fetuses (Group 1, 175-230 days; Group 2, 290-327 days with fetal cortisol concentrations $<15 \mathrm{ng} / \mathrm{ml}$ (Group 2a) or $>15 \mathrm{ng} / \mathrm{ml}$ (Group 2b), $n=5$ in each group). ${ }^{*} P<0 \cdot 05$, significant increment in concentration from basal $(0 \mathrm{~min})$ value (one-way ANOVA with repeated measures).

concentration of plasma cortisol $(r=0 \cdot 660, n=15, P<0 \cdot 01)$ and the gestational age of the fetus $(r=0 \cdot 617, n=15$, $P<0 \cdot 02)$. The relative importance of the two factors in determining the fetal $\beta$-cell response to glucose was assessed using partial correlation analysis. This showed that plasma cortisol was the predominant influence on the maximum increment in insulin in response to glucose, with no independent effect of gestational age (cortisol: $r=0.556, \quad P<0.05$; gestational age: $r=0.391, \quad P>0.05$, $n=13$ degrees of freedom). There were no significant differences in the maximum increment in plasma glucose or the glucose AUC in response to glucose administration between the three groups of fetuses (Fig. 1, Table 2).

Arginine Arginine administration to the fetus evoked a significant release of insulin in both Groups $2 \mathrm{a}$ and $2 \mathrm{~b}$ (Fig. 2). The maximum increment in insulin and the insulin AUC in response to arginine administration were similar in Groups 2a and 2b (Table 2). The peak insulin concentration occurred at the end of the 5-min infusion of arginine in both groups (Fig. 2). There was no significant correlation between the maximum increment in insulin in response to arginine and either the basal cortisol concentration or the gestational age of the fetus $(P>0 \cdot 05$, both cases). The maximum increment in $\alpha$-amino-nitrogen and in the $\alpha$-amino-nitrogen AUC were not significantly different between Groups 2a and 2b (Table 2).

\section{Discussion}

This study demonstrates that pancreatic $\beta$-cell sensitivity to glucose, but not arginine, increases in the horse fetus near term when delivery is imminent. Both the speed and magnitude of the $\beta$-cell response to glucose were greater in fetuses with plasma cortisol levels above $15 \mathrm{ng} / \mathrm{ml}$ 
Table 2 Mean ( \pm S.E.M.) values of the maximum increment and AUC for the insulin response and either the glucose or $\alpha$-amino-nitrogen response to exogenous administration of glucose or arginine in the different groups of animals (Group 1, 175-230 days, Group 2, 290-327 days with fetal cortisol concentrations $<15 \mathrm{ng} / \mathrm{ml}$ (Group 2a) or $>15 \mathrm{ng} / \mathrm{ml}$ (Group $2 b), n=5$ fetuses in each group for both the glucose and arginine challenges)

\begin{tabular}{|c|c|c|c|c|}
\hline & \multicolumn{2}{|l|}{ Insulin } & \multicolumn{2}{|c|}{ Glucose or $\alpha$-amino nitrogen } \\
\hline & $\begin{array}{l}\text { Maximum } \Delta \\
(\mu \mathrm{U} / \mathrm{ml})\end{array}$ & $\begin{array}{l}\text { AUC } \\
(\mu \mathrm{U} / \mathrm{ml} / \mathrm{min})\end{array}$ & $\begin{array}{l}\text { Maximum } \Delta \\
(\mathrm{mmol} / \mathrm{l})\end{array}$ & $\begin{array}{l}\text { AUC } \\
(\mathrm{mmol} / \mathrm{l} / \mathrm{min})\end{array}$ \\
\hline \multicolumn{5}{|l|}{ Glucose } \\
\hline Group 1 & $2 \cdot 0 \pm 1 \cdot 5^{\mathrm{a}}$ & $85 \cdot 3 \pm 50 \cdot 8^{a}$ & $6 \cdot 89 \pm 2 \cdot 22$ & $131 \cdot 7 \pm 31 \cdot 3$ \\
\hline Group 2a & $9 \cdot 9 \pm 2 \cdot 0^{a}$ & $319 \cdot 3 \pm 156 \cdot 2^{\mathrm{a}}$ & $6 \cdot 85 \pm 1 \cdot 45$ & $132 \cdot 2 \pm 29 \cdot 2$ \\
\hline Group 2b & $42 \cdot 6 \pm 5 \cdot 3^{b}$ & $1366 \cdot 3 \pm 406 \cdot 5^{b}$ & $7 \cdot 82 \pm 0 \cdot 70$ & $132 \cdot 5 \pm 13 \cdot 5$ \\
\hline \multicolumn{5}{|l|}{ Arginine } \\
\hline Group 2a & $7 \cdot 1 \pm 2 \cdot 3$ & $388 \cdot 0 \pm 145 \cdot 5$ & $3 \cdot 22 \pm 0 \cdot 25$ & $118.9 \pm 12 \cdot 5$ \\
\hline Group 2b & $9 \cdot 4 \pm 3 \cdot 6$ & $235 \cdot 5 \pm 110 \cdot 5$ & $2 \cdot 94 \pm 0 \cdot 43$ & $91 \cdot 2 \pm 12 \cdot 8$ \\
\hline
\end{tabular}

For each treatment, the values within columns with different superscript letters are significantly different from each other $(P<0 \cdot 05$, ANOVA).

(Group 2b) than in those of a similar gestational age with lower cortisol concentrations (Group 2a). The $\beta$-cell response to glucose in the Group $2 \mathrm{~b}$ fetuses closest to delivery was similar to that seen in newborn foals born spontaneously at term, while the time course and magnitude of this response in the Group 2a fetuses closely resembled that of newborn foals delivered prematurely before the final prepartum rise in fetal plasma cortisol (Fowden et al. 1982b, 1984). These observations,

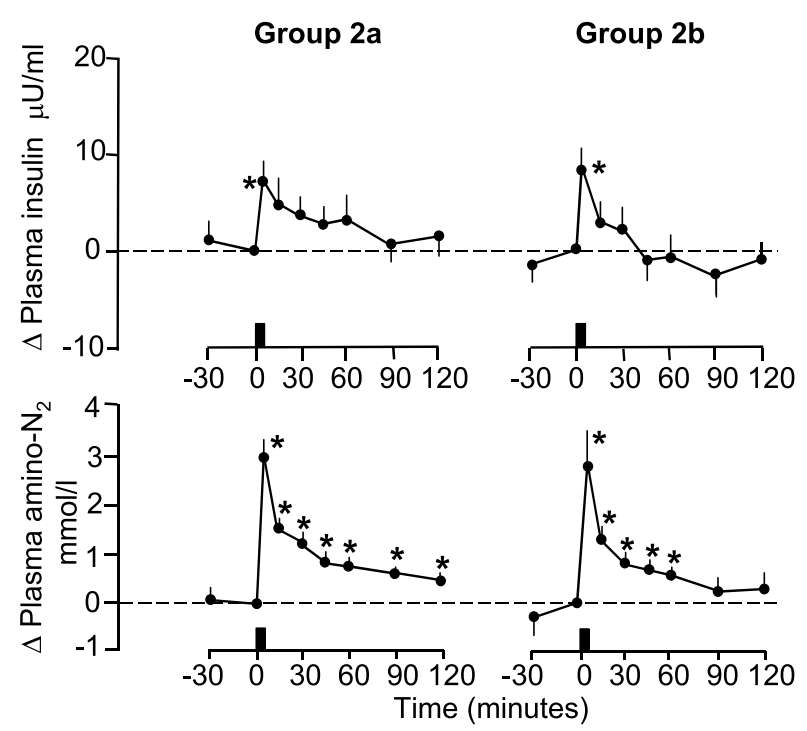

Figure 2 Mean ( \pm S.E.M.) increments in the arterial concentration of plasma insulin and $\alpha$-amino-nitrogen concentration from the basal pre-infusion $(0 \mathrm{~min})$ value after administration of arginine (solid bar) in Group 2 fetuses (290-327 days of gestation; Group $2 \mathrm{a}$, fetal cortisol concentration $<15 \mathrm{ng} / \mathrm{ml}, n=5$; Group $2 \mathrm{~b}$, fetal cortisol concentration $>15 \mathrm{ng} / \mathrm{ml}, n=5)$. ${ }^{*} P<0 \cdot 05$, significant increment in concentration from basal $(0 \mathrm{~min})$ value (one-way ANOVA with repeated measures). together with the current finding that plasma cortisol is a more important determinant of glucose-stimulated insulin secretion than gestational age, suggests that prepartum maturation of equine pancreatic $\beta$ cells may be cortisol dependent, as occurs in other fetal tissues (Fowden et al. 1998).

Glucocorticoids inhibit insulin secretion from adult $\beta$ cells in a dose- and time-dependent manner (Lambillotte et al. 1997, Jeong et al. 2001). Over-exposure to glucocorticoids during late gestation also impairs development of fetal $\beta$ cells in rodents (Blondeau et al. 2001, Shen et al. 2003, Gesina et al. 2004). In these altricial species, glycaemic control is relatively immature at birth and pancreatic development occurs late in gestation with substantial remodelling of the islets during late-fetal and early-postnatal life (Hill \& Duvillie 2000). In contrast, in precocial species, like the sheep and horse, which require good glycemic control at birth, the pancreatic islets develop much earlier in gestation and are morphologically similar to those in the adult by term (Fowden \& Hill 2001). However, when tight glycaemic control becomes essential in the rat at weaning, pancreatic $\beta$-cell sensitivity to glucose increases coincidentally with a major increment in glucocorticoid concentrations that is equivalent to the prepartum cortisol surge in the fetal horse (Fowden et al. 1998, Fowden \& Hill 2001). The effects of glucocorticoids, therefore, depend on the stage of pancreatic development at the time of exposure. During islet development in utero, glucocorticoids impair $\beta$-cell formation from the undifferentiated endocrine cells but, once the islets have formed, they induce maturation of glucose-stimulated insulin release in differentiated $\beta$ cells during a critical period just before birth.

The inability of exogenous glucose to stimulate insulin secretion in fetal horses at $50-60 \%$ of gestation is in contrast to findings in other species. In fetal sheep, insulin 
is released in response to glucose from as early as 70 days (50\% gestation) although the magnitude of the response is smaller in mid than late gestation (Fiser et al. 1974, Aldoretta et al. 1998). Similarly in rats, glucose stimulates insulin output from cultured fetal pancreas or specific $\beta$ cells from mid gestation (Girard et al. 1974). Relatively little is known about the morphological development of the equine pancreas (Helmstaedter et al. 1976) but insulin is detectable in fetal equine plasma at 120 days of gestation and rises with increases in the endogenous glucose level from as early as 175 days of gestation (Fowden et al. 1980). These observations suggest that equine $\beta$ cells at mid gestation either have limited insulin stores or are only responsive to changes in glucose that are smaller and more prolonged than the large, transient changes induced in this study by bolus administration of glucose.

In fetal sheep, the pancreatic $\beta$-cell response to glucose is affected by the availability of glucose, oxygen and catecholamines in the fetal circulation (Fowden 1980a,b, Sperling et al. 1980). In the present study, there were no changes in the basal glucose level, which could have contributed to the ontogenic increase in glucosestimulated insulin release. Neither is the fall in fetal $\mathrm{pO}_{2}$ with increasing gestational age likely to explain these ontogenic increases as low $\mathrm{pO}_{2}$ levels inhibit rather than enhance insulin secretion in the fetus (Fowden 1980a, Sperling et al. 1980). Similarly, the rise in catecholamine concentrations normally seen towards term in the fetal horse would be expected to suppress, not enhance, insulin release in response to glucose (Fowden 1980b, Sperling et al. 1980, Giussani et al. 2005). Since the fetal $\beta$-cell response to arginine was unaffected by proximity to delivery, the increment in glucose-stimulated insulin secretion between Groups $2 \mathrm{a}$ and $2 \mathrm{~b}$ in the present study is more likely to be due to increased sensitivity of the $\beta$ cells to glucose than to increases in the number or insulin content of the pancreatic $\beta$ cells.

Glucose and arginine are known to act through different mechanisms to depolarise $\beta$ cells and release insulin in the adult (Fowden \& Hill 2001). The difference in the magnitude and time course of the fetal $\beta$-cell response to arginine and glucose in this and previous studies of sheep and rats indicates that these two secretagogues also act through different mechanisms in utero (Gersch et al. 1974, Fowden 1980a, Gresores et al. 1997). In addition, the current observation that the fetal $\beta$-cell response to glucose, but not arginine, increases with proximity to delivery suggests that prepartum maturation of the insulin secretory pathways occurs upstream of $\beta$-cell depolarisation. Glucokinase, uncoupling protein (UCP) and the glucose transporter GLUT 2, all appear to be active in coupling the glucose stimulus to insulin secretion in fetal $\beta$ cells as changes in pancreatic expression of any of these genes alters insulin secretion in utero (Lamothe et al. 1998, Frayling \& Hattersley 2001, Wallace 2002, Thorens 2003). Certainly, in other tissues, there are perinatal maturational changes in the abundance of glucokinase, GLUT and UCP, which are cortisol dependent in some instances (Dawkins 1966, Sadiq et al. 1998, Mostyn et al. 2003).

In the present study, there were no changes in the basal concentrations of insulin or glucose with either gestational age or fetal cortisol concentration. This suggests that the set point for the enhanced effect of glucose on pancreatic $\beta$-cell function in late gestation is above the normal range of glucose concentrations observed in the fetal horse. The prepartum increase in glucose-stimulated insulin secretion, therefore, appears to be a maturational change that enables the $\beta$ cells to switch rapidly to regulating glycaemia at the higher glucose levels observed postnatally (Fowden et al. 1984, Ousey et al. 1995). This is consistent with previous observations of a doubling of the insulin response to exogenous glucose in fetal sheep between mid and late gestation before cortisol levels begin to rise, but a greater than 10-fold increase in the first phase of this response in newborn lambs after exposure to the prepartum cortisol surge (Philipps et al. 1979, Aldoretta et al. 1998). The prepatum rise in pancreatic $\beta$-cell sensitivity to glucose is also in keeping with many of the other prepartum maturational changes that ensure a smooth transition from parenteral to enteral nutrition at birth (Fowden et al. 2001).

\section{Acknowledgements}

We would like to thank all the members of the Department of Physiology who have helped with the animal experiments, the biochemical analyses and the production of this manuscript.

\section{Funding}

We are indebted to the Horserace Betting Levy Board for their financial support. The authors declare that there is no conflict of interest that would prejudice the impartiality of this scientific work.

\section{References}

Aldoretta PW, Carver TD \& Hay WW 1998 Maturation of glucose-stimulated insulin secretion in fetal sheep. Biology of the Neonate 73 375-386.

Armitage P \& Berry G 1994 Further analyses of straight-line data. In Statistical Analyses in Medical Research, pp 292-305. Oxford, UK: Blackwell Scientific.

Bassett JM, Madill D, Burks AH \& Pinches RA 1982 Glucagon and insulin release in the lamb before and after birth: effects of amino acids in vitro and in vivo. Journal of Developmental Physiology 4 379-389.

Blondeau B, Lesage P, Czernichow P, Dupony JP \& Breant B 2001 Glucocorticoids impair fetal $\beta$-cell development in rats. American Journal of Physiology - Endocrinology and Metabolism 281 E592-E599. 
Carver TD, Anderson SM, Aldoretta PW \& Hay WW 1996 Effect of low-level basal plus marked 'pulsatile' hyperglycaemia on insulin secretion in fetal sheep. American Journal of Physiology - Endocrinology and Metabolism 271 E862-E871.

Dawkins MJR (1966) Biochemical aspects of developing function in newborn mammalian liver. British Medical Bulletin 22 27-33.

Fiser RH, Erenberg A, Spering MA, Oh W \& Fisher DA 1974 Insulin-glucagon substrate inter-relationships in the fetal sheep. Pediatric Research 8 951-955.

Fowden AL 1980a Effects of arginine and glucose on the release of insulin in the sheep fetus. Journal of Endocrinology 85 121-129.

Fowden AL $1980 b$ Effects of adrenaline and amino acids on the release of insulin in the sheep fetus. Journal of Endocrinology 87 113-121.

Fowden AL 1993 Insulin deficiency: effects on fetal growth and development. Journal of Pediatrics and Child Health 29 6-11.

Fowden AL 1995 Endocrine regulation of fetal growth. Reproduction, Fertility and Development 7 351-363.

Fowden AL \& Hill DJ 2001 Intrauterine programming of the endocrine pancrease. British Medical Bulletin 60 123-142.

Fowden AL, Barnes RJ, Comline RS \& Silver M 1980 Pancreatic $\beta$ cell function in the fetal foal and mare. Journal of Endocrinology 87 293-301.

Fowden AL, Comline RS \& Silver M 1982a Pancreatic $\beta$ cell function in the fetal pig and sow. Quarterly Journal of Experimental Physiology 67 225-233.

Fowden AL, Ellis L \& Rossdale PD $1982 b$ Pancreatic $\beta$ cell function in the neonatal foal. Journal of Reproductive Fertility Supplement 32 $529-535$.

Fowden AL, Silver M, Ellis L, Ousey JC \& Rossdale PD 1984 Insulin secretion in the foal during the perinatal period. Equine Veterinary Journal Supplement 16 286-291.

Fowden AL, Silver M \& Conline RS 1986 The effect of pancreatectomy on the uptake of metabolites by the sheep fetus. Quarterly Journal of Experimental Physiology 71 67-78.

Fowden AL, Li J \& Forhead AJ 1998 Glucocorticoids and the preparation for life after birth: are there long term consequences of the life insurance? Proceedings of the Nutrition Society 57 113-122.

Fowden AL, Forhead AJ, Bloomfield M, Taylor PM \& Silver M 1999 Pancreatic $\alpha$ cell function in the fetal foal during late gestation. Experimental Physiology 84 697-705.

Fowden AL, Ousey JC \& Forhead AJ 2001 Comparative aspects of prepartum maturation; provision of nutrients. Pferdeheikunde $\mathbf{1 7}$ $653-658$

Frayling TM \& Hattersley AT 2001 The role of genetic susceptibility in the association of low birth weight with Type 2 diabetes. British Medical Bulletin 60 89-102.

Gersch JE, Charles MA \& Grodsky GM 1974 Characterisation of the effects of arginine and glucose on glucagon and insulin release from the perfused rat pancreas. Journal of Clinical Investigation 54 833-841.

Gesina E, Tronche F, Herrera P, Duchene B, Tales W, Czernichow P \& Breant B 2004 Dissecting the role of glucocorticoids on pancreas development. Diabetes 53 2322-2339.

Girard J, Devran A, Soufflet E \& Assan R 1974 Factors affecting the secretion of insulin and glucagon by the rat. Diabetes 23 310-317.

Giussani DA, Forhead AJ \& Fowden AL 2005 Development of cardiovascular function in the horse fetus. Journal of Physiology 565 1019-1030

Gresores A, Anderson S, Hood D, Zerbe GO \& Hay WW 1997 Separate and joint effects of arginine and glucose on ovine fetal insulin secretion. American Journal of Physiology - Endocrinology and Metabolism 272 E68-E73.

Hay WW 1995 Regulation of placental metabolism by glucose supply. Reproduction, Fertility and Development 7 365-375.

Helmstaedter V, Feurle GE \& Forssman WG 1976 Insulin-, glucagons-, and somatostatin-immunoreactive endocrine cells in the equine pancreas. Cell and Tissue Research 172 447-454.
Hill DJ \& Duvillie B 2000 Pancreatic development and adult diabetes. Pediatric Research 48 269-274.

Jackson BT, Piasecki GJ, Cohn HE \& Cohen WR 2000 Control of fetal insulin secretion. American Journal of Physiology - Regulatory, Integrative and Comparative Physiology 279 R2179-R2188.

Jeong IK, Oh SH, Kim BJ, Chung JH, Min YK, Lee MS, Lee MK \& Kim KW 2001 The effects of dexamethasone on insulin release and biosynthesis are dependent on the dose and duration of treatment. Diabetes Research and Clinical Practice 51 163-171.

Lambillotte C, Gilon P \& Henquin JC 1997 Direct glucocorticoid inhibition of insulin secretion: an in vitro study of dexamethasone effects in mouse islets. Journal of Clinical Investigation 99 414-423.

Lamothe B, Baudry A, Desbois P, Lanotte L, Bucchni D, De-Meyts P \& Joshi RL 1998 Genetic engineering in mice: impact on insulin signalling and action. Biochemical Journal 335 193-204.

Lang U, Jensen A \& Kunzel W 1993 Automatic modulation of insulin levels in foetal sheep. Clinical Autonomic Research 3 331-338.

Mostyn A, Pearce S, Budge H, Elme M, Forhead AJ, Fowden AL, Stephenson T \& Symonds ME 2003 Influence of cortisol on adipose tissue development in the fetal sheep during late gestation. Journal of Endocrinology 176 23-30.

Ousey JC, Ghatei M, Rossdale PD \& Bloom SR 1995 Gut hormone responses to feeding in healthy pony foals aged 0-7 days. Biology of Reproduction Monographs 1 87-96.

Philipps AF, Dubin JW \& Raye JR 1979 Response of the fetal and newborn lamb to glucose and tolbutamide infusion. Pediatric Research 13 1375-1378.

Rossdale PD 1967 Clinical studies on the newborn Thoroughbred foal. I Perinatal behaviour. British Veterinary Journal 123 470-481.

Rossdale PD, Silver M, Ellis L \& Frauenfelder H 1982 The response of the adrenal cortex to tetracosactrin $\left(\mathrm{ACTH}_{1-24}\right)$ in the premature and full term foal. Journal of Reproductive Fertility Supplement 32 $545-553$.

Sadiq HF, DeMello D \& Devaskar SW 1998 The effect of intrauterine growth restriction upon fetal and postnatal hepatic glucose transporter and glucokinase proteins. Pediatric Research 43 91-100.

Shen C-N, Seckl JR, Slack JMW \& Tosh D 2003 Glucocorticoids suppress $\beta$-cell development and induce hepatic metaplasis in embryonic pancreas. Biochemical Journal 375 41-50.

Silver M \& Fowden AL 1994 Prepartum adrenocortical maturation in the fetal foal: response to ACTH (1-24). Journal of Endocrinology 142 417-425.

Sperling MA, Christensen RA, Ganguli S \& Anand R 1980 Adrenergic modulation of pancreatic hormone secretion in vivo: studies in fetal sheep. Pediatric Research 14 203-208.

Taylor PM, White KL, Fowden AL, Giussani DA, Bloomfield M \& Sear JW 2001 Propofol anaesthesia for surgery in late gestation pony mare. Veterinary Anaesthesia and Analgesia 28 177-187.

Thorens B 2003 A gene knockout approach in mice to identify glucose sensors controlling glucose homeostasis. Pflugers Archives 445 482-490.

Trahair J \& Sangild PT 1997 Systemic and luminal influences on the perinatal development of the gut. Equine Veterinary Journal Supplement 24 40-50.

Wallace AC (2002) Animal models of mitochondrial disease. Methods in Molecular Biology 197 3-54.

Received in final form 24 June 2005

Accepted 27 June 2005 